\title{
Biomass and leaf dynamics of Cymodocea nodosa in the Ria Formosa lagoon, South Portugal
}

\author{
Alexandra H. Cunha ${ }^{1, a, *}$ and Carlos M. Duarte ${ }^{2}$ \\ ${ }^{1}$ Instituto da Conservacão da Natureza (ICN), Parque \\ Natural da Ria Formosa, Quinta de Marim, 8700 Olhão, \\ Portugal, e-mail: acunha@ualg.pt \\ 2 Instituto Mediterraneo de Estudios Avanzados \\ IMEDEA (CSIC-UIB), Miquel Marqués 21, \\ 07190 Esporles, Illes Balears, Spain \\ * Corresponding author
}

\begin{abstract}
We describe shoot density, aboveground and belowground biomass, form and leaf production per shoot over a one-year cycle for Cymodocea nodosa meadows in the Ria Formosa lagoon (South Portugal). Habitat conditions in Ria Formosa allow the development of lush meadows (up to 1752 shoots $\mathrm{m}^{-2}$ ), supporting high shoot biomass (up to $945 \mathrm{~g} \mathrm{DW} \mathrm{m}^{-2}$ ), high leaf productivity (up to $14 \mathrm{~g}$ DW $\mathrm{m}^{-2} \mathrm{~d}^{-1}$ ) and large shoots (up to $113 \mathrm{~cm}$ leaf length) despite being located at the northern limit of the distributional range in the Atlantic Ocean. Biomass in the meadows examined is higher than other Atlantic sites with $C$. nodosa, and comparable to the most productive seagrass meadows yet reported. Shoot morphometry and biomass distribution were variable within Ria Formosa, with the stands growing in muddy sediments having a lower ratio of belowground/aboveground biomass than those in sandy sites. C. nodosa had a clear unimodal growth cycle, reaching maximum leaf development in summer. Mean leaf length and number of leaves per shoot, the rate of appearance of new leaves and the rate of leaf fall, average leaf growth and leaf turnover rates $(P / B)$ were minimal in February and March, and maximal in July and September. The high production of the meadows examined may be related to the high nutrient availability in Ria Formosa, evidenced by the high leaf nutrient content $(3.4 \%$ of DW and $0.38 \%$ of DW for nitrogen and phosphorus, respectively).
\end{abstract}

Keywords: Cymodocea nodosa; leaf production; Portugal; Ria Formosa; seagrasses.

\section{Introduction}

The seagrass Cymodocea nodosa (Ucria) Ascherson is widely distributed throughout the Mediterranean Sea and the North-Atlantic coast of Africa, reaching its southern limit in Senegal (den Hartog 1970, Afonso-Carrillo and Gil-Rodríguez 1980, Lüning 1990). Most studies on the

\footnotetext{
a Present address: Centro de Cięncias do Mar (CCMAR), Universidade do Algarve, Campus de Gambelas, 8005-139 Faro, Portugal.
}

phenology and biomass of the species have been conducted in the Mediterranean Sea (Caye and Meinesz 1985, Peduzzi and Vukovič 1990, Buia and Mazella 1991, Terrados and Rós 1992, Pérez et al. 1994, Mostafa 1996, Rismondo et al. 1997, Agostini et al. 2003, Terrados et al. 2006), whereas research on the biomass and growth of the species in the Atlantic coast is limited to observations in North Africa, including those in the Canary Islands (Reyes 1993, Reyes et al. 1995), and Mauritania (Van Lent et al. 1991, Vermaat et al. 1993).

This seagrass forms extensive meadows in Ria Formosa in southern Portugal, which, together with scattered patches along the southwestern Portuguese coast (Alberto personal observations 2004), represents the known northern limit of the species in the Atlantic Ocean. Analysis of the genetic structure of the Cymodocea nodosa meadows in Ria Formosa suggested that this population was likely introduced from a single male "founder" clone (Alberto et al. 2001), which may be derived from either the northern Africa or the Mediterranean meadows. A further peculiarity of Ria Formosa as a habitat for Cymodocea nodosa is that it is a highly productive, nutrient-rich system [nitrate concentrations up to $8.8 \mu \mathrm{M}$, phosphates up to $5.6 \mu \mathrm{M}$ and ammonium concentrations up to $108 \mu \mathrm{M}$ (Falcão and Vale 1990)], whereas all other Atlantic meadows investigated grow in oligotrophic or mesotrophic environments (Wolff et al. 1993, Pérez et al. 1994). The growth of Cymodocea nodosa is often nutrient-limited (Pérez et al. 1994), so growth and production in Ria Formosa may be particularly high.

Here we describe density, biomass, form and leaf production per shoot over a one-year cycle of Cymodocea nodosa meadows in the Ria Formosa lagoon (southern Portugal). We first describe plant form, biomass, both aboveground and belowground, and shoot density at the time of maximal biomass in summer, and then examine leaf growth and leaf dynamics over one year to estimate the annual leaf production per shoot of sites of contrasting sediment conditions in Ria Formosa.

\section{Materials and methods}

\section{Study site}

The Ria Formosa is a multi-inlet, barrier island system located in southern Portugal $\left(37^{\circ} 10^{\prime} \mathrm{N}, 8^{\circ} 03^{\prime} \mathrm{W}\right.$, and $36^{\circ} 57^{\prime} \mathrm{N}, 7^{\circ} 31^{\prime} \mathrm{W}$ ). Its present configuration consists of two peninsulas and five islands that extend over $50 \mathrm{~km}$ (Pilkey et al. 1989). Connection between the ocean and the back barrier area is made through six tidal inlets. According to Andrade 1990, the total area of this system is $1.7 \times 10^{7} \mathrm{~m}^{2}$, with the back barrier area consisting mainly of salt marsh and small sandy islands making up a 
complicated pattern of tidal channels and creeks. The saltmarsh species Sarcocornia perennis, Spartina maritima, and the seagrass Zostera noltii dominate the intertidal zone, while the seagrass Cymodocea nodosa dominates the subtidal zone with scattered patches of Zostera marina (Cunha and Duarte 2005). No meadows were observed in the intertidal zone, suggesting that Cymodocea nodosa cannot tolerate emersion.

Although the main navigation channel, the Faro channel, can reach $30 \mathrm{~m}$ in depth, the average depth of the lagoon is $2 \mathrm{~m}$ below mean sea level (msl) (Andrade 1990).

Fresh water input into the lagoon is low, and salinity remains close to 36 psu except during sporadic and short periods of winter run-off (Falcão and Vale 1990). Water temperature ranges annually from 12 to $26^{\circ} \mathrm{C}$, and dissolved oxygen in the water column remains close to or above saturation levels (Falcão and Vale 1990). Tides in the area are semi-diurnal, average ranges are $2.8 \mathrm{~m}$ for spring tides and $1.3 \mathrm{~m}$ during neap tides; however, maximum ranges of $3.5 \mathrm{~m}$ can be reached. This pattern causes important semi-diurnal and fortnightly tidal fluctuations of water volume inside the system (Falcão and Vale 1990).

\section{Morphometry, biomass, density and leaf nutrient content}

Shoots and rhizomes of Cymodocea nodosa were collected during spring tides of August 1993 in stations S1, S2, MS3, M4, M5 (Table 1). We extracted six to nine $20 \mathrm{~cm}$ diameter cores from each site to a depth about $40 \mathrm{~cm}$ in the sediment (to include all living rhizomes). Cores were taken about $50 \mathrm{~cm}$ from one another. We counted all shoots of the rhizome pieces in the sample, counted and measured the lengths and widths of all entire leaves of each shoot and the sheaths, and counted and measured the length of the entire root. Leaf and root lengths reported are the sum of all leaves and roots, respectively. Leaves plus sheaths account for aboveground biomass. Leaves and sheaths, horizontal and vertical rhizomes, and roots were dried for $24 \mathrm{~h}$ at $70^{\circ} \mathrm{C}$ and weighed for total shoot biomass estimates.

Leaf nutrient contents were determined in duplicate sub-samples collected near station MS3 (August 1993). Nitrogen concentrations in leaves were determined using a Carlo-Erba (Milan, Italy) $\mathrm{CHN}$ analyzer, and tissue $\mathrm{P}$ concentrations were determined by colorimetry in dupli-

Table 1 Cymodocea nodosa: stations sampled in Ria Formosa; sediment and sampling type.

\begin{tabular}{llll}
\hline & $\begin{array}{l}\text { Sediment } \\
\text { type }\end{array}$ & $\begin{array}{l}\text { Sampled for } \\
\text { biomass }\end{array}$ & $\begin{array}{l}\text { Sampled for leaf } \\
\text { dynamics }\end{array}$ \\
\hline S1 & Sand & $\mathrm{x}$ & \\
S2 & Sand & $\mathrm{x}$ & $\mathrm{x}$ \\
MS3 & Mixed & $\mathrm{x}$ & $\mathrm{x}$ \\
M4 & Mud & $\mathrm{x}$ & $\mathrm{x}$ \\
M5 & Mud & $\mathrm{x}$ & \\
M6 & Mud & & $\mathrm{x}$ \\
M7 & Mud & & $\mathrm{x}$ \\
\hline
\end{tabular}

Biomass was sampled during August 1993, and leaf dynamics from August 1993 to August 1994. cate sub-samples after wet acid digestion (Koroleff 1983).

\section{Leaf dynamics}

Following a preliminary survey, we selected five Cymodocea nodosa meadows around the lagoon for leaf dynamics assessment. The criteria used for meadow selection was based on the choice of sites that would be representative of a range of substratum present in Ria Formosa, from mud to sand, S2, MS3, M4, M6, M7 (Table 1). All sampling sites were partially emergent during lowwater tide periods allowing sampling without SCUBA.

Leaf growth was followed for 13 months (August 1993-September 1994). In each meadow, 20 shoots were marked by perforating all the leaves just above the bundle sheath with a pin (Zieman 1974); they were marked with a plastic strip attached to the shoot. The marked shoots were collected every 30 days. Shoot parameters such as total leaf length (the sum of the length of all leaves), total number of leaves, and new leaves per shoot were measured for each shoot. Leaf epiphytes were removed with a scalpel, and leaves were dried for $24 \mathrm{~h}$ at $70^{\circ} \mathrm{C}$, and weighed.

Leaf growth $\left(\mathrm{cm} \mathrm{shoot}^{-1} \mathrm{~d}^{-1}\right)$ was estimated by adding the growth in length of each shoot's leaves, and dividing by the number of days of growth. Shoot leaf production (g DW shoot ${ }^{-1} \mathrm{~d}^{-1}$ ) was estimated from the amount of biomass that was produced by the leaves during the marking period, divided by the number of days of growth. We estimated the average turnover rate $(\mathrm{P} / \mathrm{B})$ by calculating the ratio between average shoot production and its total biomass, and dividing by the number of days of growth. New leaf appearance rate (leaves shoot ${ }^{-1} \mathrm{~d}^{-1}$ ) was estimated for each marked period by:

New leaf appearance rate $=$ no. of new leaves/(no. of marked shoots $\times$ days of growth)

The plastochrone interval (days) for each marking period (i.e., number of days between new and consecutive leaf appearance) was estimated as the inverse of the rate of new leaf appearance.

The rate of leaf loss (leaves shoot ${ }^{-1} \mathrm{~d}^{-1}$ ) between two sampling events was estimated by:

Leaf loss $=\left[\left(\right.\right.$ no. of leaves lo $_{t 0}$ + no. of new leaves)-no. of leaves $\left.{ }_{t 0+1}\right] / t$

\section{Results}

\section{Morphometric data, biomass and leaf nutrient content at a peak season}

The meadows were dense (up to 1752 shoots $\mathrm{m}^{-2}$; Table 2) and supported high total shoot biomass (up to $945 \mathrm{~g}$ DW $\mathrm{m}^{-2}$; Figure 1). The shoots had numerous short roots, and their combined biomass with the high rhizome biomass resulted in a high belowground biomass that exceeded the aboveground biomass for meadows grow- 
Table 2 Cymodocea nodosa: leaf, sheath and root morphometry during peak season (August) for meadows S1, S2, MS3, M4, M5, and leaf nutrient content for MS3, in Ria Formosa.

\begin{tabular}{|c|c|c|c|c|c|}
\hline & S1 & S2 & MS3 & M4 & M5 \\
\hline Leaves $\left(\right.$ shoot $\left.^{-1}\right)$ & $3.1 \pm 0.1$ & $2.6 \pm 0.1$ & $2.5 \pm 0.1$ & $2.7 \pm 0.1$ & $2.7 \pm 0.1$ \\
\hline Total leaf length $\left(\mathrm{cm} \mathrm{shoot}^{-1}\right)$ & $57.5 \pm 2.0$ & $113 \pm 5.8$ & $66.2 \pm 3.0$ & $68.0 \pm 3.5$ & $62.5 \pm 3.5$ \\
\hline Leaf width $(\mathrm{mm})$ & $53 \pm 2$ & $45 \pm 1$ & $45 \pm 1$ & $47 \pm 1.5$ & $43 \pm 0.9$ \\
\hline Leaf area index $\left(\mathrm{m}^{2} \mathrm{~m}^{-2}\right)$ & 3.0 & 5.5 & 2.5 & 4.1 & 3.2 \\
\hline Sheath length (cm) & $10.3 \pm 0.2$ & $9.7 \pm 0.2$ & $9.0 \pm 0.3$ & $12.2 \pm 0.4$ & $11.6 \pm 0.4$ \\
\hline Shoot density $\left(\mathrm{m}^{-2}\right)$ & $1005 \pm 96$ & $1162 \pm 137$ & $950 \pm 190$ & $1752 \pm 468$ & $1311 \pm 191$ \\
\hline No. roots $\left(\right.$ shoot $\left.^{-1}\right)$ & $6.3 \pm 1.0$ & $3.6 \pm 0.8$ & $5.0 \pm 0.5$ & $4.9 \pm 0.6$ & $4.8 \pm 0.5$ \\
\hline Total root length $\left(\mathrm{cm} \mathrm{shoot}^{-1}\right)$ & $11.5 \pm 0.5$ & $11.8 \pm 0.5$ & $12.7 \pm 0.9$ & $10.8 \pm 0.6$ & $12.0 \pm 0.7$ \\
\hline Ratio belowground/aboveground & $1.9 \pm 0.1$ & $2.2 \pm 0.1$ & $4.2 \pm 0.4$ & $1.1 \pm 0.1$ & $0.8 \pm 0.1$ \\
\hline Leaf nitrogen content (\% DW) & & & 3.4 & & \\
\hline Leaf phosphorus content (\% DW) & & & 0.38 & & \\
\hline
\end{tabular}

Means \pm SE are reported (number of shoots examined per meadow=200). Site codes in Table 1.

ing in sand (S1 and S2) and mixed sediment (MS3). In meadows growing on mud (M4 and M5), the ratio of belowground/aboveground biomass was close to 1.0 (Figure 1). There was, however, considerable variation in shoot morphometry and biomass distribution within sites. Number of leaves per shoot varied from 2.5 in the mixed sediment site (MS3) to 3.1 in the sandy site (S2). The shoots had long leaves, with a total leaf length per shoot ranging from $57 \mathrm{~cm}$ to over $1 \mathrm{~m}$ in the sandy site. Leaf width varied from $43 \mathrm{~mm}$ in the muddy site to $53 \mathrm{~mm}$ in the sandy site. Leaf area index ranged from 2.5 to $5.5 \mathrm{~m}^{2} \mathrm{~m}^{-2}$ and sheath length from 9.0 to $12.2 \mathrm{~cm}$ (Table 2). Leaf nutrient content was measured for only the mixed sediment site and was $3.4 \%$ and $0.38 \%$ of DW for nitrogen and phosphorus, respectively.

\section{Leaf dynamics}

The meadows displayed a clear unimodal growth pattern, reaching maximum leaf development in summer, reflecting the high variation in water temperature, which during the period of study ranged from $5^{\circ} \mathrm{C}$ in winter to $28.5^{\circ} \mathrm{C}$ in summer. Mean leaf length per shoot varied from a minimum of $22.5 \mathrm{~cm}$ during March to $113 \mathrm{~cm}$ in July (Figure 2). The mean rate of new leaf appearance rate was low from December to March (0.008 leaves shoot $\left.{ }^{-1} \mathrm{~d}^{-1}\right)$ and high in July with a rate of 0.10 leaves per shoot per day (Figure 3). The average rate of leaf loss followed a similar pattern (Figure 3), with a minimum that varied between 0 to 0.02 leaves shoot ${ }^{-1} \mathrm{~d}^{-1}$ from December to March, and

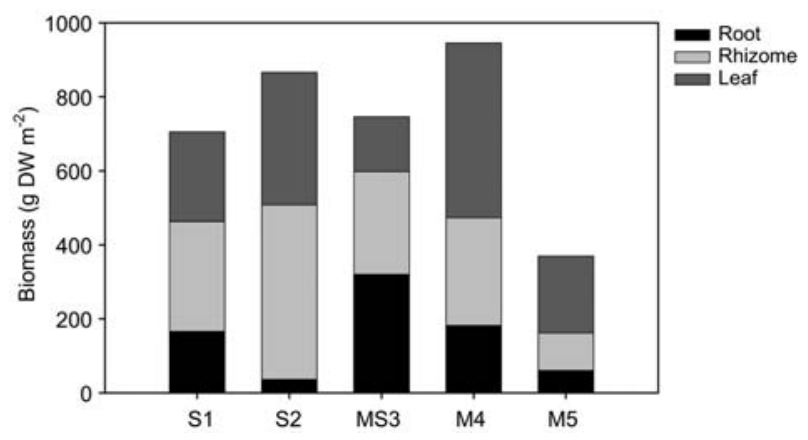

Figure 1 Cymodocea nodosa: mean total shoot (leaves and sheath, rhizomes and roots) biomass during peak season (August) at five sites (S1, S2, MS3, M4, M5) in Ria Formosa. a maximum ranging from 0.05 to 0.10 leaves shoot ${ }^{-1} \mathrm{~d}^{-1}$ during June and July.

Leaf production varied between $0.5 \mathrm{mg} \mathrm{DW}$ shoot $^{-1}$ $\mathrm{d}^{-1}$ in spring, and $8.3 \mathrm{mg}$ DW shoot ${ }^{-1} \mathrm{~d}^{-1}$ in summer (Figure 2). Leaf turnover rate $(P / B)$ varied between $0.009 \mathrm{~d}^{-1}$ in winter and $0.034 \mathrm{~d}^{-1}$ in summer (Figure 2). The number of leaves produced per shoot in one year was 14 for the stand at M4 station (the only station that we were able to follow for 13 months), calculated directly through the leaf marking method. This implies that the plastochrone interval was 26 days for this meadow.

\section{Discussion}

The Cymodocea nodosa population described in this study, growing at the northern limit of the distributional range in the Atlantic Ocean, has comparable and sometimes higher growth rates than stands in locations to the south and east. Leaf area index (LAI) during peak season growth was comparable to those generally found in the Mediterranean Sea $\left(3.9 \mathrm{~m}^{2} \mathrm{~m}^{-2}\right.$, Caye and Meinesz 1985; $4.0 \mathrm{~m}^{2} \mathrm{~m}^{-2}$, Pérez 1989; $1.8 \mathrm{~m}^{2} \mathrm{~m}^{2}$, Terrados and Rós 1992) and the Canary Islands (3.9 $\mathrm{m}^{2} \mathrm{~m}^{-2}$, Reyes 1993), but lower than in plants in the Bay of Piran $\left(7.2 \mathrm{~m}^{2} \mathrm{~m}^{-2}\right.$, Peduzzi and Vukovič 1990) and in the lagoon of Venice (8.2 $\mathrm{m}^{2} \mathrm{~m}^{-2}$, Rismondo et al. 1997). Although shoot density is somewhat lower than those found in other sites (2060 shoot $\mathrm{m}^{-2}$, Caye and Meinesz 1985; 2000 shoot $\mathrm{m}^{-2}$, Pérez 1989; 1900 shoot $\mathrm{m}^{-2}$, Terrados and Rós 1992; 1928 shoot $\mathrm{m}^{-2}$, Reyes 1993; 2302 shoots $\mathrm{m}^{-2}$, Rismondo et al. 1997; 1520 shoots $\mathrm{m}^{-2}$, Agostini et al. 2003), with the exception of plants growing in Montazah Bay (404 shoots $\mathrm{m}^{-2}$, Mostafa 1996) and Banc d'Arguin (576 shoots $\mathrm{m}^{-2}$, Van Lent et al. 1991), the shoots in Ria Formosa occur at higher biomass than those generally observed in the Mediterranean Sea, Mar Menor (170 g DW m²- Terrados and Rós 1992), Alfaques Bay (785 g DW m². Pérez et al. 1994), Montazah Bay (287 g DW $\mathrm{m}^{-2}$, Mostafa 1996), as well as those from the few Atlantic meadows on the North African coast that have been studied, viz. Canary Islands (592 g DW m², Reyes 1993), Banc d'Arguin (391 g DW m-2, Vermaat et al. 1993). However, biomass results are comparable to the growth observed in the Bay of Piran (1020 g DW m², Peduzzi and Vukovič 1990), lagoon of Venice (1710 g DW m-2, 

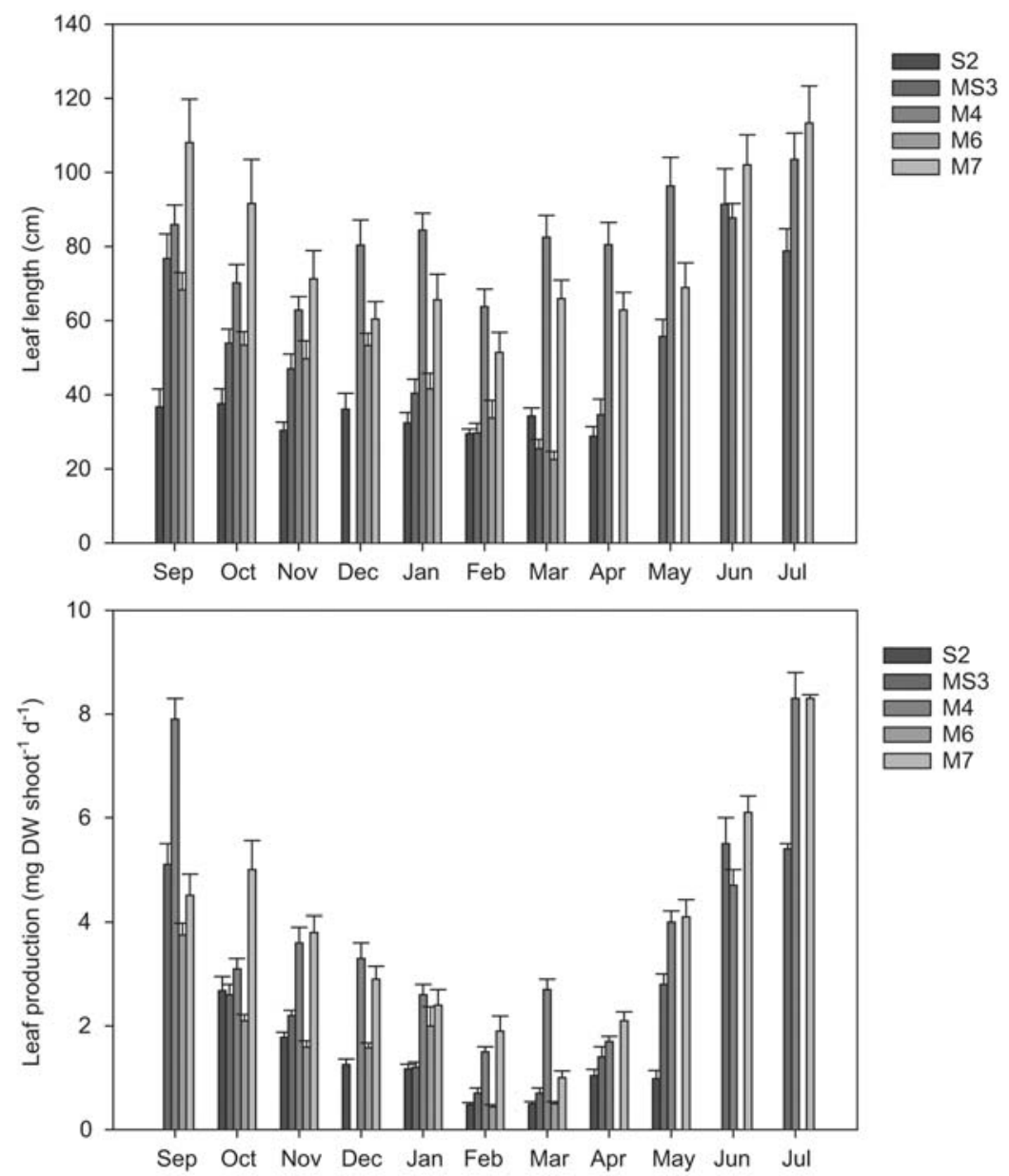

M6

$\square$ M7



Figure 2 Cymodocea nodosa: total mean leaf length $(\mathrm{cm})(+\mathrm{SE})$, rate of mean leaf production (g DW shoot $\left.{ }^{-1} \mathrm{~d}^{-1}\right)(+\mathrm{SE})$ and mean leaf turnover rate $(\mathrm{P} / \mathrm{B} ;+\mathrm{SE})$ through the year for the five sites sampled (S2, MS3, M4, M6 and M7).

Rismondo et al. 1997) and the lagoon of Urbino (1090 $\mathrm{g}$ DW m², Agostini et al. 2003). Cymodocea nodosa biomass is dependent on the nutrient status of the meadow (Pérez et al. 1994), suggesting that the eutrophic nature of Ria Formosa lagoon is a determining factor for the large Cymodocea nodosa shoots there. Indeed, C. nodosa leaf nutrient concentrations in Ria Formosa are the highest yet reported for this species (Duarte 1990). The high values of biomass and production found for the Bay of Piran in the Gulf of Trieste (Peduzzi and Vukovič 1990), lagoon of Venice (Rismondo et al. 1997) and for the lagoon of Urbino (Agostini et al. 2003) might also be related to nutrient availability in these lagoons. Indeed, Diaz and Rosenberg (1995) describe the Gulf of Trieste as being an eutrophic region, and Bianchi et al. (2004) found a high concentration of nitrates and ammonium in the lagoon of Venice. There are no published nutrient records for the lagoon of Urbino.

There was, however, considerable variation in shoot morphometry and biomass distribution within Ria Formosa, with the stands growing in muddy sediments having a lower ratio of belowground/aboveground biomass 

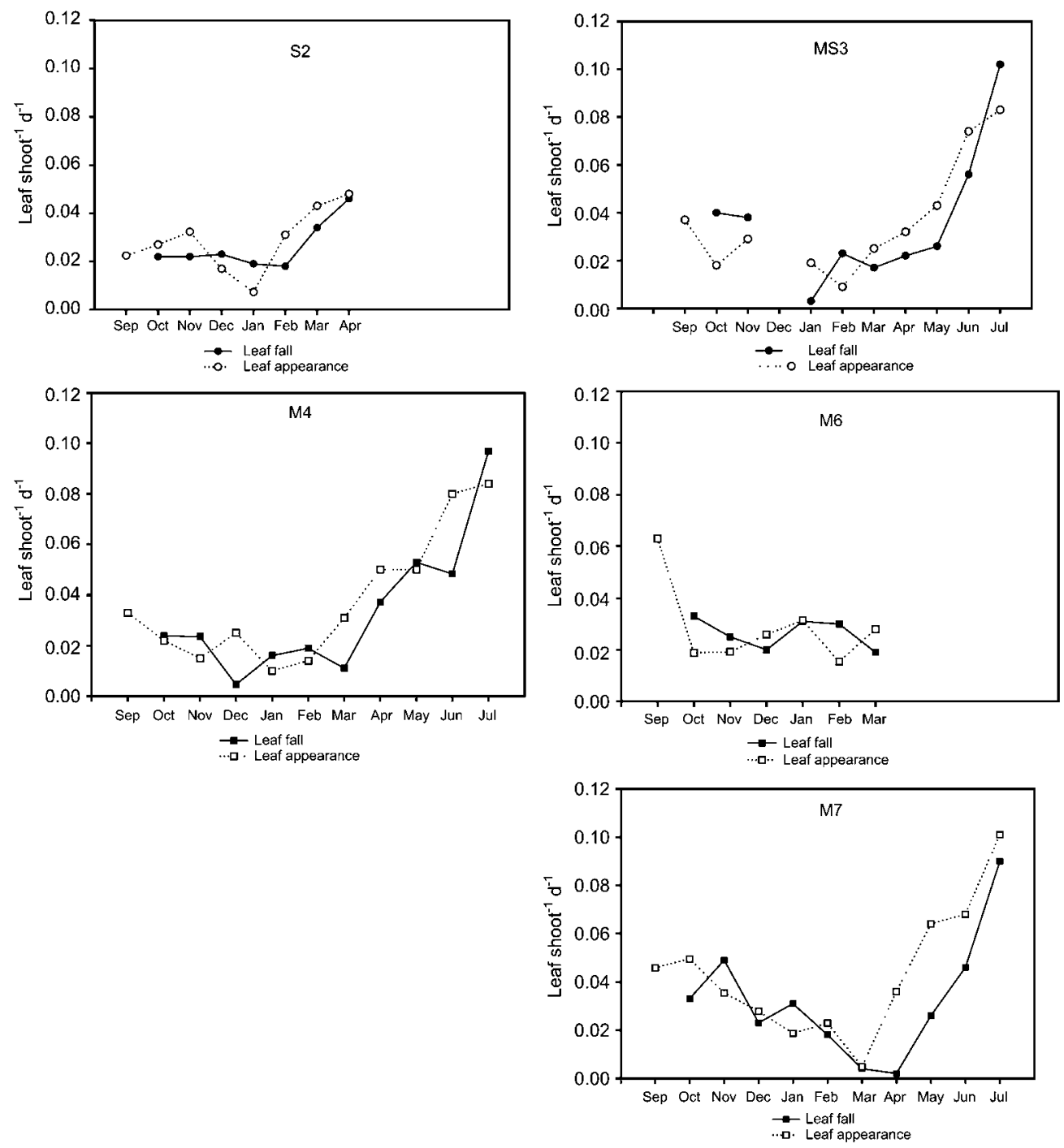

Figure 3 Cymodocea nodosa: rates of new leaf production and loss (leaf fall and leaf appearance) for five sites (S2, MS3, M4, M6 and $\mathrm{M} 7$ ).

than those in sandy sites. These findings are similar to observations by Terrados and Rós (1992) in the Mar Menor and Reyes (1993) in the Canary Islands.

Leaf production estimates during peak season (up to $14 \mathrm{~g} \mathrm{DW} \mathrm{m}^{-2} \mathrm{~d}^{-1}$ ) was substantially greater for Ria Formosa than those estimated for the Mediterranean regions of Bay of Piran (2.8 g DW m-2 $\mathrm{d}^{-1}$, Peduzzi and Vukovič 1990) and for the Mar Menor (1.5 g DW m $\mathrm{g}^{-2} \mathrm{~d}^{-1}$, Terrados and Rós 1992), but are quite close to the leaf production observed in the lagoon of Venice (12.3 g DW $\mathrm{m}^{-2} \mathrm{~d}^{-1}$, Rismondo et al. 1997) and the Urbino lagoon (17.5 $\mathrm{g} \mathrm{DW} \mathrm{m}^{-2} \mathrm{~d}^{-1}$, Agostini et al. 2003). The extent of annual variability in leaf size, growth, production and appearance and loss rates in the Cymodocea nodosa meadows studied was high, as observed for other temperate $C$. nodosa meadows, exceeding that for the Mar Menor meadows (0.5-0.8 mg DW shoot $^{-1}$ day $^{-1}$ for May-July; Terrados and Rós 1992) and subtropical meadows in the Canary Islands (Reyes et al. 1995). Leaf growth was highest from June to July, and leaf productivity per shoot per day peaked during July and August, whereas these parameters were minimal during February. Reyes et al. (1995) found a similar leaf growth pattern in the Canary Islands, although the minimum values in Ria Formosa are delayed by two months in relation to the Canary Islands. The period of minimal and maximal leaf number found for meadows in Ria Formosa is also delayed by one to two months in relation to that in the Canary Islands. The high seasonality of $C$. nodosa in Ria Formosa is likely related to the very broad temperature range recorded there $\left(23^{\circ} \mathrm{C}\right)$. Although the range of values differed, the rate of leaf appearance is similar in temporal patterns to those observed in Mediterranean meadows (Terrados and Rós 1992, Pérez et al. 1994) and on the Canary Islands (Reyes et al. 1995). As observed by these authors, the maximal and minimal rates of leaf appearance and leaf fall coincide in time, which reflects the higher rates of leaf renovation in spring and summer (May-July). The rate of leaf loss observed by Reyes et al. (1995) in the Canary Islands was minimal in February (0.012 leaf shoot-1 $\left.\mathrm{d}^{-1}\right)$ and maximal (0.049-0.057 shoot $\left.^{-1} \mathrm{~d}^{-1}\right)$ in May and July, one month earlier than in Ria 
Formosa. Leaf turnover rates are in the same range as those found for Mar Menor (0.004-0.028, Terrados 1992), but the maximum turnover rate for $C$. nodosa populations in Ria Formosa (0.034, this study) is the highest reported to date (0.003-0.018 in Delta del Ebro, Pérez 1989; and 0.012-0.018 in the Canary Islands, Reyes 1993).

The number of leaves produced in one year is close to estimates using the reconstruction methods for the same population in Ria Formosa (Cunha and Duarte 2005) and for other locations ( 11 leaves shoot ${ }^{-1} \mathrm{y}^{-1}$, Caye and Meinesz 1985; 13 leaves shoot ${ }^{-1} \mathrm{y}^{-1}$, Pérez 1989; 10 leaves shoot $^{-1} \mathrm{y}^{-1}$, Peduzzi and Vukovič 1990; 11-12 leaves shoot $^{-1} \mathrm{y}^{-1}$, Terrados 1991, Terrados and Rós 1992; 13 leaves shoot ${ }^{-1} \mathrm{y}^{-1}$, Reyes 1993) and confirm that the annual number of leaves produced by Cymodocea nodosa shoots is relatively constant. In summary, the results reported here indicate that habitat conditions in the Ria Formosa lagoon allow the development of lush meadows supporting highly productive and large shoots, despite being located at the northern limit of the distributional range in the Atlantic Ocean. Production of the meadows examined is comparable to the most productive seagrass meadows yet reported (Duarte and Chiscano 1999).

The factors limiting the distribution of Cymodocea nodosa in the Atlantic Ocean are unlikely to be determined by poor growth conditions or low temperatures. C. nodosa meadows in Ria Formosa appear to derive from a single (male) clone (Alberto et al. 2001), implying that sexual reproduction is limited in Ria Formosa. The limit of distribution of the plant in the Atlantic Ocean may be imposed by perturbations to the reproductive system, or other bottlenecks in the plant's life cycle, or to disturbance. The origin of this population (from Mediterranean, African or Macronesian stocks) is now being addressed (Alberto unpublished data).

\section{Acknowledgements}

This project was funded by Institute for Nature Conservation (ICN)-Natural Park of Ria Formosa, Portugal. The authors express their gratitude to the park rangers for assistance in the field.

\section{References}

Afonso-Carrillo, J. and M.C. Gil-Rodríguez. 1980. Cymodocea nodosa (Ucria) Ascherson (Zannichelliaceae) y las praderas submarinas o sebadales en el Archipiélago Canario. Vieraea 8: 365-376.

Agostini, S., G. Pergent and B. Marchand. 2003. Growth and primary production of Cymodocea nodosa in a coastal lagoon. Aquat. Bot. 76: 185-193.

Alberto, F., L. Mata and R. Santos. 2001. Genetic homogeneity in the seagrass Cymodocea nodosa at its Northern Atlantic limit revealed through RAPD. Mar. Ecol. Progr. Ser. 221: 299-301.

Andrade, C.F. 1990. O ambiente de barreira da Ria Formosa, Algarve, Portugal. Ph.D. Dissertation. University of Lisbon, Portugal. pp. 627.

Bianchi, F., E. Ravagnan, F. Acri, F. Bernardi-Aubry, A. Boldrin, E. Camatti, D. Casin and M. Turchetto. 2004. Variability and fluxes of hydrology, nutrients and particulate matter between the Venice lagoon and the Adriatic Sea. J. Mar. Syst. 51: 49-64.
Buia, M.C. and L. Mazzella. 1991. Reproductive phenology of the seagrass Posidonia oceanica (L.) Delile, Cymodocea nodosa (Ucria) Ascherson, and Zostera noltii Hornem. Aquat. Bot. 40: 343-362.

Caye, G. and A. Meinesz. 1985. Observations on the vegetative development, flowering and seedling of Cymodocea nodosa (Ucria) Ascherson on the Mediterranean coasts of France. Aquat. Bot. 22: 277-289.

Cunha, A.H. and C.M. Duarte. 2005. Population age structure and rhizome growth of Cymodocea nodosa in Ria Formosa (Southern Portugal). Mar. Biol. 146: 841-847.

den Hartog, C. 1970. The seagrasses of the world. North Holland, Amsterdam. pp. 275.

Diaz, R.J. and R. Rosenberg. 1995. Marine benthic hypoxia: a review of its ecological effects and the behavioural responses of benthic macrofauna. Oceanogr. Mar. Biol. Ann. Rev. 33: 245-303.

Duarte, C.M. 1990. Seagrass nutrient content. Mar. Ecol. Prog. Ser. 67: 201-207.

Duarte, C.M. and C.L. Chiscano. 1999. Seagrass biomass and production: a reassessment. Aquat. Bot. 65: 159-174.

Falcão, M. and C. Vale. 1990. Study of the Ria Formosa ecosystem: benthic nutrient remineralization and tidal variability of nutrients in the water. Hydrobiologia 207: 137-146.

Koroleff, F. 1983. Determination of phosphorus. In: (K. Grasshoff, M. Ehrardt and K. Kremling, eds) Methods of seawater analysis. 2nd edition. Verlag Chemie, Nürnberg. pp. 125-139.

Lüning, K. 1990. Seaweeds. Their environment, biogeography, and ecophysiology. Wiley-Interscience, New York. pp. 527.

Mostafa, H.M. 1996. Preliminary observations of the seagrass Cymodocea nodosa (Ucria) Ascherson in the Mediterranean waters of Alexandria, Egypt. Bull. Nat. Inst. of Oceanogr. and Fish., A. R. E. 22: 19-28.

Peduzzi, P. and A. Vukovič. 1990. Primary production of Cymodocea nodosa in the Gulf of Trieste (Northern Adriatic Sea): a comparison of methods. Mar. Ecol. Prog. Ser. 64: 197-207.

Pérez, M. 1989. Fanerogamas marinas en sistemas estuarieos: production, factores limitantes y algunos aspectos del ciclo de nutrients. Doctoral thesis, University of Barcelona, Spain. pp. 244.

Pérez, M., C.M. Duarte, J. Romero, K. Sand-Jensen and T. Alcoverro. 1994. Growth plasticity in Cymodocea nodosa meadows: the importance of nutrient supply. Aquat. Bot. 47: 249-264.

Pilkey, O.H., J.H. Monteiro and J.M.A. Dias. 1989. Algarve barrier islands: a non-coastal plain system in Portugal. J. Coastal Res. 2: 239-261.

Reyes, J. 1993. Estudio de las praderas marinas de Cymodocea nodosa (Cymodoceaceae, Magnoliophyta) y su comunidad de epífitos, en El Médano (Tenerife, Islas Canarias). Tesis Doctoral, University of La Laguna. pp. 424.

Reyes, J., M. Sansón and J.A. Afonso-Carrillo. 1995. Distribution and reproductive phenology of the seagrass Cymodocea nodosa (Ucria) Ascherson in the Canary Islands. Aquat. Bot. 50: $171-180$

Rismondo, A., D. Curiel, M. Marzocchi and M. Scattolin. 1997. Seasonal pattern of Cymodocea nodosa biomass and production in the Lagoon of Venice. Aquat. Bot. 58: 55-64.

Terrados, J. 1991. Crecimiento y production de las praderas de macrófitos del Mar Menor, Murcia. Doctoral thesis, University of Murcia, Spain. pp. 229.

Terrados, J. and J.D. Rós. 1992. Growth and primary production of Cymodocea nodosa (Ucria) Ascherson in a Mediterranean lagoon: the Mar Menor (SE Spain). Aquat. Bot. 43: 63-74.

Terrados, J., M. Grau-Castella, D. Pinõl-Santina and P. RieraFérnandez. 2006. Biomass and primary production of a 8-11 $m$ depth meadow versus $<3 \mathrm{~m}$ depth meadows of the seagrass Cymodocea nodosa (Ucria) Ascherson. Aquat. Bot. 43: 63-74.

Van Lent, F., P.H. Nienhuis and J.M. Verschuure. 1991. Production and biomass of the seagrass Zostera noltii Hornem. and 
Cymodocea nodosa (Ucria) Ascherson at the Banc d'Arguin (Mauritania, NW Africa): a preliminary approach. Aquat. Bot. 41: 353-367.

Vermaat, J.E., J.A.J. Beijer, R. Gijlstra, M.J.M. Hootsmans, C.J.M. Philipart, N.W. van den Brink and W. van Vierssen. 1993. Leaf dynamics and standing stocks of intertidal Zostera noltii Hornem. and Cymodocea nodosa (Ucria) Ascherson on the Banc d'Arguin (Mauritania). Hydrobiologia 258: $59-72$.
Wolff, W.J, J. van der Land, P.H. Nienhuis and P.A.W.J. de Wilde. 1993. The functioning of the ecosystem of the Banc d'Arguin, Mauritania: a review. Hydrobiologia 258: 211-222.

Zieman, J.C. 1974. Methods for the study of the growth and production of turtle grass Thalassia testudinum König. Aquaculture 4: 139-143.

Received 9 December, 2005; accepted 2 March, 2007 